\title{
The Plea for Asia-Tan Yunshan, Pan-Asianism and Sino-Indian Relations
}

\author{
Brian Tsui
}

\begin{abstract}
In 1927, the Buddhist scholar, Tan Yunshan, travelled to Santiniketan on the invitation of Rabindranath Tagore to teach Chinese at Visva Bharati University. Subsequent years would see him develop close ties with the Guomindang and Congress leaders, secure Chinese state funding for the first sinological institute in India and mediate between the nationalist movements during the Second World War. That a relatively marginal academic, who participated in neither the May Fourth Movement nor any major political party, and who had little prior experience of India, could have played such an important role in twentieth century Sino-Indian relations raises questions over the conditions that made possible Tan's illustrious career. This article argues that Tan's success as an institution builder and diplomatic intermediary was attributable to his ideological affinity with the increasing disillusionment with capitalist modernity in both China and India, the shifting dynamics of the Pan-Asianist movement and the conservative turn of China's nationalist movement after its split with the communists in 1927. While Nationalist China and the Congress both tapped into the civilizational discourse that was supposed to bind the two societies together, the idealism Tan embodied was unable to withstand the conflict of priorities between nationstates in the emerging Cold War order.
\end{abstract}

The academic Tan Yunshan (1898-1983) played a pivotal role in Sino-Indian relations before the advent of the Indian nation-state. As an individual, Tan might have preferred that his efforts focused on promoting educational ties between the two countries. Yet, Tan never strayed too far from politics. After all, Tan operated in a world dominated by formal and 'informal' empires, an Asia where liaisons between political movements across societies had to depend on such cosmopolitan figures like himself. Whereas 'apolitical' traders, professionals and academics could travel relatively freely between Asian societies thanks to the looming presence of Pax Britannica, movement was more restricted for nationalist activists who wished to communicate with each other on how to put an end to colonialism. The relationship between semi-colonial China and British India was no exception. That a private citizen was to occupy a significant mediating role in bringing the two movements together was hardly surprising.

CHINA REPORT $46: 4$ (2010): 353-370

SAGE Publications Los Angeles/London/New Delhi/Singapore/Washington DC DOI: $10.1177 / 000944551104600403$ 
Yet, as an individual, Tan was no natural candidate for being the premier intermediary between Nationalist China and the Indian National Congress. Tan received a modern education in his native Hunan province (C. Tan 1999; L. Tan 1999). ${ }^{1}$ Before joining Visva Bharati as a lecturer in Chinese studies, he was a publisher, newspaper editor and educator, but had little knowledge and experience of India. Spending much of his earlier life in Hunan and Malaya, Tan was unfamiliar with the cultural scenes of Beijing and Shanghai-the two centres of modern Chinese intellectual and political experimentations. A classmate of Mao Zedong regardless, Tan stayed away from organized party politics, and never became a member of either the Guomindang (GMD) or the Chinese Communist Party. While a supporter of the modern vernacular, Tan was not among the New Culture intellectual radicals or party activists who went on to occupy important positions in the educational and political institutions under Chiang Kai-shek's nationalist government. As far as the tumultuous political and cultural life of early twentieth century China is concerned, Tan Yunshan was a marginal academic who was socially and geographical removed from the centres of gravity.

Under a changed set of circumstances, however, Tan's peripheral status vis-à-vis China's intellectual radicalism was to make him an ideal operator in Sino-Indian interactions in lieu of state-to-state diplomacy. It is these circumstances that constitute the subject matter of my article. I argue that personal acumen and tenacity aside, a convergence of shifting political and ideological forces in China and beyond, from the late 1920s, worked to bring the two nationalist movements together, a process to which Tan was eminently capable of contributing. These favourable conditions included the increasing unease with capitalist modernity in the institutionalized nationalisms of both societies; the shifting dynamics of the Pan-Asianist movement in view of Japan's continental adventurism; and the drastic conservative turn of the GMD after being hijacked by its fervently anti-communist right wing. The break-up of the GMD's alliance with the communists resulted in the former's retreat from not only radical social programmes but also Communist International (Comintern)-sponsored anti-colonial activities. Having renounced anti-imperialist internationalism, the GMD, still seeing itself as a revolutionary party, privileged civilizational affinities in its engagements with other colonized Asian peoples. Tan's ambiguous politics and distance from May Fourth radicalism appealed to the GMD's conservative cosmopolitanism.

By examining the wider historical milieu that shaped Tan's career, this article seeks to supplement the few comprehensive biographical accounts of this remarkable figure. In addition, I hope this article will contribute to an assessment of the cosmopolitan anti-colonial programme Tan embodied-one based on romanticized pre-colonial ties between civilizations, desires for the revival of Asia and an idealist commitment to global unity. Just as Sino-Indian alliance was facilitated by schisms in the imagined solidarity among Asian peoples due to Japan's geopolitical designs in the 1930s, Nationalist

\footnotetext{
${ }^{1}$ For biographical introductions to Tan Yunshan's career, see the contributions of his sons, Tan Lee and Tan Chung, in C. Tan (1999) and L. Tan (1999).
}

China Report 46, 4 (2010): 353-370 
China's relations with independent India were marred by the diverging positions of the two nation-states in the emerging Cold War order, despite the continued evocation of their supposed inalienable religious and cultural bonds. Confronting the nature and limits of the fragile GMD-Congress alliance is of utmost importance, not least because deep engagement between cultures continues to be evoked as a possible alternative to calculations of economic and strategic interests that define interactions between nation-states today.

\section{RETURN TO ASIA}

It is hard to imagine that Tan, in spite of his distance from Chinese intellectual life, was unaware of the politics with which he was associating himself when he accepted Tagore's invitation to teach at Visva Bharati in 1927. If nothing else, Tan would have recalled Tagore's controversial visit to China in 1923. Amidst the efflorescence of social radicalism in anticipation of the revolutionary alliance between the GMD and the recently formed Chinese Communist Party, the reception of Tagore among young Chinese intellectuals was unenthusiastic, if not downright hostile. Widely revered in Europe and in much of Japan, the first Asian recipient of the Nobel Prize for Literature was enmeshed in the polarized cultural politics of the May Fourth period, being identified with the traditional Eastern spirituality embraced by the Late Qing reformer Liang Qichao, who headed the literary association behind the visit. That Tagore insisted throughout his trip that he was nothing more than a poet wishing for the revival of China and Asia's great spirit did not help relieve the anxieties of political radicals, who saw in the towering Bengali visitor vindication for either a nostalgic 'return' to the comfort of an idealized traditional order or an aestheticist withdrawal from the social ills that required nothing less than fundamental changes. While most Chinese intellectuals had high regard for the Nobel laureate's literary accomplishments, particularly his contributions to the modern Bengali vernacular literature, Tagore's cosmopolitan catholicity did not go down well with the left wing of the May Fourth generation. Tagore's well-advertised aversion to mass mobilization and his critique of nationalism were anathema to a communist party about to take on board and radicalize Sun Yat-sen's nationalist agendas. The communist intellectual Qu Qiubai, for instance, faulted Tagore not mainly for the latter's elevation of Oriental spirituality but for his cavalier dismissal of the nation-state (guojia) as a potent means to mobilize the masses for anti-imperialist and progressive endeavours $(\mathrm{Qu}$ 1988: 511-59).

It was thus not until four years after his disappointing visit that Tagore would find a Chinese ideological companion in Tan Yunshan. The young scholar, unimpressed with the social radicalism of his peers who gathered around Marxist study groups and the two major political parties, went to British Malaya in 1924 and became a teacher and newspaper editor with the Chinese community. Tan's serious interest in Buddhism

China Report 46, 4 (2010): 353-370 
began two years earlier, when he was baptized under Master Taixu, the pre-eminent Buddhist modernist in Republican China. Intriguingly, Taixu's involvement in the republican revolutionary movement, and his eclectic programme bringing together the idealist tenets of the Faxiang School and Henri Bergson's vitalism, appealed to intellectuals on not only the right but also the left, such as the early Qu Qiubai (Cheung 2007: 56-70). While Qu would eventually convert to historical materialism and advocate proletarian revolution, Tan's Buddhism was to inform his analysis of the relevance of Sino-Indian interaction to a world fraught by the spiritual crisis brought about by liberal capitalism.

The Great War, better known in China as the 'European War' (Ou zhan), redrew the political contours of the early twentieth century world. In the wake of the prolonged orgy of violence, liberal ideologies of linear progress, evolutionism and positivism and the institutions of capitalist modernity were challenged not only by Marxist revolutionaries but also by the radical right. Intellectuals like Bergson, Oswald Spengler and Martin Heidegger provided ideological ammunition for the politics of conservative revolution - a 'return' to the communitarian ethos of organic nations and an urge to overcome the dehumanizing effects of capitalism while keeping the private property system mostly intact. In China, Bergson, Spengler and the conservative humanist, Irving Babbitt, were touted by Liang Qichao, Zhang Junmai and others committed to the search for a 'humanistic' alternative to state socialist and liberal capitalist modernities. Civilization discourse became an important feature in non-revolutionary critiques of the Enlightenment project. The resultant politics is ridden with contradictions. Prasenjit Duara observes that desire for a superior universal order to Enlightenment civilization was a core element of anti-imperialist projects and that even the bourgeois nationalist quest for a territorially bound, culturally distinct nation-state contains within itself impulses of transcendence (Duara 2003: 91-96). The peripatetic lay Buddhist embodied this contradiction of interwar civilization discourse. Furthermore, civilization, even as an analytical category targeting particular societies, is conceived of as describing an 'undetermined' collective subjectivity that stands aloof from social and economic processes (Sartori 2008: 37-38). While the inherent ambiguities of Tan's Pan-Asianist dismissal of the West distanced the man's ideas from racist or overtly nationalist sentiments, the metaphysical neglect of social relations and privileging of cultural revivalism as anti-colonialist strategy would nonetheless endear Tan to the post-1927 nationalist regime, as the party-state reneged on its recent progressive past and worked to neutralize the 'threat' of communist revolution.

\section{GMD'S CONSERVATIVE REVOLUTION AND THE QUEST FOR DATONG}

Tan Yunshan's cordial relationship with Nanjing began as late as 1930, when he joined a delegation of nationalist state representatives on a mission to Lhasa. Fresh from

China Report 46, 4 (2010): 353-370 
the victory of the Northern Expedition, Nanjing was anxious to assert claims over the financially impoverished but independently governed Tibet (Lin 2006: 51-71). The dramatic trip saw Tan play, for the first time, the role of unofficial diplomat, as Chiang Kai-shek's envoy, Xie Guoliang, died from illness before setting foot on Tibetan territory. Aside from delivering Chiang's messages to the Dalai Lama, Tan authored a report to Nanjing lamenting how it was disgraceful that Chinese nationals had to travel to purportedly Chinese soil via British India (Zhu 2006: 107-16). Thus, in 1931 when Tan acted on Tagore's vision, alluding to the Buddhist monk Xuanzang's pilgrimage to India during the seventh century, to 're-establish' ties between the two cultures, he already had access to the upper echelons of the GMD state. The senior GMD functionary behind Nanjing's funding of Cheena Bhavana, Dai Jitao, would have known of Tan not least because of the former's own interest in frontier affairs (bianzheng).

Dai, then head of the largely powerless Examination Yuan, was more well known as theoretician of the GMD right and for his interest in Buddhism. A former socialist and translator of Karl Kautsky, Dai provided important ideological ammunition for the right-wing coup d'état that ousted the communists from the GMD. The 1927 coup marked the GMD's shift from a vanguard of the radicalized nationalist revolution (guomin geming) to the agent of what might be called China's 'conservative revolution'. According to Dai's theorization, a GMD rid of communist influence would be a better weapon against capitalist excesses (Dai 1951). Like most right-wing movements that began their careers on the left, the GMD did not repudiate socialism outright but claimed to incorporate its principles (Neocleous 1997: 38-40). Thus, Dai argued that Sun Yat-sen's 'principle of livelihood' (minsheng zhuyi) encapsulated the same ideals as socialism, only that the means to achieving these goals were different. These means included state management of productive forces, harnessing the nation's collective will, but definitely not the abolition of private property (Dai 1951: 7, 19). Indeed, by obliterating class politics and actively suppressing the revolutionary agency of the proletariat, the GMD, after 1927, was committed to an anti-revolutionary revolution. Given the GMD's appropriation of socialism, one could easily imagine the polarized reception in China of what Tan remembered as Tagore's uniquely perceptive 'advice' to radicalized Chinese youth in 1934: don't adopt the Soviet system, for China had its own version of communism (Tan 1946: 6).

The international dimension of the GMD's conservative turn mirrored the party-state's domestic programme. Under the united front with the communists, the GMD participated actively in Comintern-sponsored anti-colonial activities. The GMD sent the largest delegation to the 1927 League against Imperialism conference, at which the Indian National Congress, represented by Jawaharlal Nehru, was also a participant (Prashad 2007: 16-30). The reasons for Dai's displeasure with communist internationalism were plain. China could not afford to contribute to world revolution before securing its own independence and economic development (Dai 1928: 8-11).

China Report 46, 4 (2010): 353-370 
In other words, proletarian rootlessness was anathema to nationalism. China could only appeal to international sympathy through 'peaceful' means, lest Comintern antiimperialism result in further 'international oppression' (ibid.). Rather than confronting imperialism, Dai prescribed gradualism, conciliation and a revolution of consciousness. As the economy waited for development with the help of 'German science and American machinery', the GMD could work not on empowering the masses, but, in his typical Buddhism-infused diction, bringing about confidence, spiritual renewal and self-awakening (juewu) (ibid., 14, 25). Cooperation with foreign capital, along with a renewal of the Confucian cosmopolitan virtues of benevolence and universal love, would somehow free China and other Asian peoples from the shackles of imperialism and capitalism and propel the world to a blissful state of great union (datong), a Confucian concept that also appealed to Tan (Dai 1951: 27-29). Dai's anti-capitalist rhetoric regardless, his appeal to peace, spirituality and civilizational unity amounted to a denial of organized confrontation with imperialism and global capitalism.

Institutionally, the displacement of the GMD's foreign engagement from socialist internationalism to Confucian Pan-Asianism took the form of the New Asia Society, a party-funded body inaugurated in 1931, in none other than the premises of the Examination Yuan. Echoing late imperial states' management of areas beyond China proper, the New Asia Society was committed to the revival of all Asian civilizations, including both foreign peoples and what the nationalists considered as non-Han Chinese such as Tibetans and the Manchus (Kubo 2002: 81). Aside from opinions on how best to integrate the contested areas on China's peripheries into Nanjing's national space, the society's in-house publication, New Asia, promoted overseas nationalist movements that the editors deemed ideologically commendable. ${ }^{2}$ The Indian 'revolution', as the Congress-led independence movement was called, featured prominently in the journal, with Tan a main interpreter of Gandhi's political programme. Deeply impressed by Gandhi's principle of non-violence, Tan wrote regularly on his meetings with senior Congress members and translated the Mahatma's writings into Chinese, including a piece on the dalit (ibid., 88-124). Tan's interest in Gandhian anti-colonialism and social engineering resonated with Dai, who responded enthusiastically to Tagore's call for 'renewing' cultural ties between China and India. The great 'Draftsman of the Chinese Nationalist Party', Tan enthused, 'ha[d] the profoundest love and greatest respect' for India and the Congress. Deemed the Chinese equivalent of Nehru, Tan further noted the GMD elder's achievements in wresting Sun Yat-sen's political philosophy away from communist appropriation by drawing on 'traditional values' and appealing to 'nationalistic and democratic revolution' rather than class struggle (Tan 1948: iv). Having rejected cooperation with communism, the GMD and the Indian anti-colonial movement could still maintain their ties by appealing to Pan-Asianism, nationalism and a shared wariness of social revolution.

\footnotetext{
${ }^{2}$ For a sampling of New Asia articles on China's 'frontier', see Duara (2003: 190-201).
} 


\section{REMEMBERING XUANZANG}

Tagore's disdain for the exclusionary and violent tendencies in nationalist mobilization is well documented (Guha 1992: 76-90). Yet, the boundary between Tagore's idealization of Asian aesthetic spirituality and right-wing nationalist politics was often blurry. In the midst of the Russo-Japanese War, he congratulated Japanese soldiers for refusing to be 'mere cogs in the wheel' and repudiating Western mechanized warfare through their willingness to sacrifice for their emperor (Bharucha 2006: 58). It would be unreasonable to expect Tagore to foresee that absolute loyalty towards the emperor, like Pan-Asian unity, would become a core feature of Japanese ultranationalism in the 1930s. As a critic of nationalism and continental expansionism, the Bengali poet and his many admirers in Japan indeed did not see eye to eye. Yet, while Tagore was consistent in his denunciation of nationalistic violence, which he associated with Western industrial modernity, he was much less forthright in confronting ideological strands that informed Japanese expansion into continental Asia. Thus, in his renowned debate with the Japanese modernist poet Yone Noguchi, Tagore's categorical denunciation of Japan's aggression against China was juxtaposed with the striking lamentation that 'the land of Bushido, of great Art and traditions of noble heroism' was being conquered by the 'scientific savagery' of modern mass warfare (Tagore 1999: 209). The violence that appalled Tagore so deeply was inseparable from what he saw as the fundamental flaw of capitalist modernity: the reduction of valiant humanity into the Taylorized average masses deployed in not only industrialized warfare but also political mobilization of both the left and the right. It was as much Japan's submission to Western modernity as the devastation it brought upon the rest of Asia that rendered Noguchi's vision of a Pan-Asianist alliance against Western imperialism disingenuous. Nationalistic activism stemming from nostalgia for traditional hierarchies and orders, or the voluntarism of a disciplined mass, did not trouble Tagore quite that much (Guha 1992: 79-89). Refusing to interrogate how anti-modernist celebration of Asian spiritual purity and vitality might have been an integral part of Japanese militarism, Tagore simply shifted his Pan-Asianist longing from 'the land of Bushido' to Chiang Kai-shek's 'unconquerable' China (Tagore 1999: 210).

Not coincidentally, on the Chinese side, it was Dai Jitao who used to wax lyrical on the indomitable Japanese spirit before the Second Sino-Japanese War. The party ideologue urged his compatriots to appreciate the martial (shangwu) yet gentle (pinghe) and cooperative (huzhu) spirit of the Japanese, which he attributed to a combination of Japan's native Shinto and Confucian and Buddhist teachings the country imported from China and India (Dai 2005: 156-57). The virile life of the Japanese stood in sharp contrast to the debauchery and effeminacy of China, where people engaged in ongoing political strife and 'meaningless debates' (ibid., 39). Factional struggles were rife within the GMD, but it was improbable that Dai was not also thinking about the communist ideological challenge as he appealed for national unity and his increasingly untenable wish for China and Japan to join hands to revive Asia. In fact,

China Report 46, 4 (2010): 353-370 
cultural and racial affinities aside, alliance with the staunchly anti-communist Japan was a way for Nationalist China to counter the influence of Soviet Russia, which Dai deemed as China's natural nemesis (Dai 1959a: 372). Exorcizing his party's recent history of involvement in socialist internationalism, Dai's Pan-Asianism was pitched as an alternative anti-Western alliance. The dream of a Sino-Japanese anti-imperialist alliance was soon dashed, but GMD Pan-Asianists soon found a more amiable partner in Gandhi's nationalist movement and associated figures like Tagore and Tan.

When Tan travelled to Nanjing to raise funds for Visva Bharati's Chinese studies programme, he benefitted from the gradual convergence of Chinese and Indian PanAsianisms. Tan's return to China coincided with the Guandong Army's invasion of Manchuria and the subsequent establishment of Manchukuo, an empire-building process steeped in Pan-Asianist discourses and practices associated with Japan's radical right (Duara 2003: 111-22). As Dai finally became disillusioned with Japan's ambitions, he and his colleagues in the nationalist state increased their support for Tagore's representative. In 1933, the Sino-Indian Cultural Society in China was initiated in Nanjing, with a view to funding cultural and academic ties with India. The Indian chapter of the society was founded a year later in Santiniketan. Senior members of nationalist parties from both countries served in the committees of their corresponding chapters. The Indian chapter's list of honorary presidents included figures of no lesser stature than Gandhi, Nehru, Chiang Kai-shek and his wife. Its own claim of being 'non-political' nonetheless, the society was unmistakably a product of the vicissitudes of Asia's two biggest nationalist movements. ${ }^{3}$

The Sino-Indian Cultural Society and the nationalist regime gave substantial financial backing to the vision of an alliance between China and India, mediating contact between Nanjing and the Congress through the 1930s and the 1940s without unduly alarming the British Raj. The alliance was crafted in terms of a disinterested relationship between two great Asian civilizations, in sharp contrast to the tension-ridden, and often violent, interaction between modern European states. Tagore's 1937 speech marking the opening of the Chinese-funded Cheena Bhavana, or Chinese Hall, at Visva Bharati amounted to nothing less than a proposal for an alternative world order to the capitalist system of competing nation-states. Sino-Indian relations, Tagore declared, would not be beset by conflicting interests because the Indians, as a colonized people, did not have a state. India's lack, however, would prove to be an advantage since 'not know[ing] how to help you or injure you materially', Tagore and his compatriots could be nothing other than 'your guests, your hosts, your brothers and your friends'. He categorically condemned capitalist globalization and its attendant system of nationstates, decrying that 'in a world so closely knit by railways, steamships and air lines', a 'wrong kind of nearness' brought about a 'terrorised world' of blunder, oppression and invasion at the expense of 'peaceful races' (Tagore 1957b: 42). He hailed what he

\footnotetext{
${ }^{3}$ See, for example, the back cover of Sino-Pamphlet No. 11, Goodwill Messages to India, which ironically carries a collection of Dai Jitao's speeches delivered in India.
}

China Report 46, 4 (2010): 353-370 
saw as the first step towards revitalizing India and China's 'exchange of gifts' as 'noble friends' as an antidote to the alienation and violence of industrial modernity. 'The moral force which has given quality to our civilization' - cooperation and love, mutual trust and mutual aid - would empower humans to 'assimilate' twentieth century scientific advances. Otherwise, Tagore warned in apocalyptic language, science would 'dominate and enslave them' (Tagore 1957b: 41-43). Tagore's generous musing of a harmonious global order centred on Sino-Indian cultural fusion was echoed by Dai when he visited Cheena Bhavana in 1940. Dai saw the revival of Sino-Indian interaction, the origins of which he traced to Tagore's 1923 visit to China, as signs of the two countries regaining their past glory. Rejuvenated circulation of Buddhist art, personnel and scriptures between the two societies was touted as important contributions to world peace and human welfare (Dai 1959c: 1291-92).

Tagore and Dai's idealization of Sino-Indian cultural fusion free from consideration of competing interests between nation-states was reflected in the research and teaching programmes at Cheena Bhavana. Chinese and Indian languages, literatures, history, religions and philosophy were all under the purview of the institute, but 'Buddhism [was] regarded as the nucleus of all such studies' (General Rules of Visva-Bharati, 1937; cited in Tan 1957: 20). One highlight of Cheena Bhavana’s publication programme was the 'restoration' of lost Sanskrit works that were translated into Chinese or Tibetan since the seventh century into Indian languages (Rules Regarding Studies in CheenaBhavana, 1937; cited in Tan 1957: 20). Aside from scholars of Indian, Chinese and Tibetan Buddhism, faculty members had expertise in the languages, philosophy and art of the three cultures. Compared to classical studies and religion, modern topics were given much less attention. Except for one specialist who worked on modern Chinese literature, nobody at Cheena Bhavana wrote anything substantial on modern topics. The only scholar who wrote regularly on modern China and its relations with India was Tan Yunshan (Tan 1957: 56-59). The day-to-day functioning of Cheena Bhavana conformed to Tagore and Dai's romantic retracing of the trail blazed by the seventh century Chinese Buddhist monk Xuanzang.

\section{PAN-ASIANISM IN ACTION}

Cheena Bhavana's privileging of philological and classical studies does not mean that the institute shied away from contemporary politics. The escalating violence in Asia and other parts of the world embroiled Cheena Bhavana deeply in the geopolitics of the Pacific War, particularly the delicate issue of how to reconcile the Pan-Asianist desire for an ethical world order centred on an alliance between independent India and China and the ongoing persistence of the British Raj. The urgency that engulfed Santiniketan was well captured in a 1939 letter Tagore sent to Tan, who was then in China mediating between the GMD and the Congress as Japan encroached further

China Report 46, 4 (2010): 353-370 
into continental Asia. Tagore urged Tan to return to India, suggesting that he could help China's cause better by 'disseminating true news about the Sino-Japanese conflict' against 'the ever progressing Japanese propaganda' (Tagore 1957a: 40). By 1939, indeed, regular contact between Nanjing and the Congress had been established. Two Congress presidents, Nehru and Subhas Chandra Bose, both from the party's left wing, had expressed support for China's resistance against Japan, and Dai was to be the first senior nationalist to visit India a year later (Dai 1959e: 1645; L. Tan 1999: 6). In retrospect, it is tempting to see these developments as the beginning of a wartime Pan-Asianist alliance between Nationalist China and the Indian independence movement.

Reality, however, was much less sanguine. Not all members of the Congress were willing to join British India's war efforts against Japan, especially when the colonizers were reluctant to meet the party's demand for independence. Not a few Indian nationalists were unsurprisingly sympathetic to Japan's Pan-Asianism, with which Tagore and Dai were once fascinated. Bose's abrupt switch in 1941 to allying with Japan and mobilization of militant Indians attracted to Japan's call for an anti-imperialist Asian alliance was no doubt the most scandalous case of Indian nationalism's vicissitudes vis-à-vis Japanese imperialism. Yet even Gandhi, who was hardly a Pan-Asianist, expressed as late as April 1942 that he was willing to negotiate with the Japanese empire as long as independence was secured for India. As a bourgeois nationalist, he was under pressure from industrialists who feared destruction of their properties during fighting between Allied forces and the Japanese. It was Nehru who convinced Gandhi and the Congress at large to support Allied forces in their India-based activities (Voigt 2004: 366-67).

Gandhi's assurance to Chiang that all the Congress's decisions would 'lead to the strengthening of India's and China's defence' in July 1942 was thus a result of intense political manoeuvring in which Cheena Bhavana played an indispensable role. Tan heeded Tagore's call and went back to Santiniketan, focusing his energy on galvanizing Indian popular support for China by contributing to nationalist journals like the Modern Review. As Principal of Cheena Bhavana, he hosted Dai Jitao in 1940 and facilitated the first, and coincidently the last, face-to-face dialogue between Tagore and a senior nationalist official. In February 1942, Chiang Kai-shek, now the supreme commander of Allied forces of the China theatre, spent two days in Santiniketan with his wife while on an official visit to New Delhi. There, the Chiangs held a series of talks with Nehru, by far the most sympathetic among Congress leaders to China's cause. The talks followed those held during Nehru's visit to Chongqing in 1939. Nehru's support for China was reciprocated by Chiang's open plea to Britain for Indian independence. That the 'private' Cheena Bhavana was a GMD-sponsored concretization of the modern spiritual construction called Asia provided a most fitting backdrop for discussion of Sino-Indian collaboration. Adding to the significance of the Cheena Bhavana as the realization of GMD's Pan-Asianist longings, the Chiangs donated 80,000 rupees to the institute, of which 50,000 went to a memorial dedicated to the recently deceased Rabindranath Tagore.

China Report 46, 4 (2010): 353-370 
Yet, even as Nehru's anti-Japanese stance was adopted as official Congress policy, the united front presented by China and the Indian independence movement was unstable from the beginning. The Sino-Indian alliance was forged by appealing partly to the two societies' cultural commonality as 'Asian', and partly to a mutual revulsion of foreign intrusion. The alliance did not imply agreement on the strategies necessary to rid the two countries of imperialism, or indeed on the reasons for much of Asia's subjugation under foreign political and economic interests. The Pan-Asianist enterprise that brought Tagore's humanism, Tan's Buddhism and Dai's conservative cosmopolitanism together lacked a socio-political vision. Grounded in the aesthetic instead of the socio-economic, Pan-Asianism as sponsored by the GMD called for a global order of ethical renewal. During his visit to Cheena Bhavana in January 1940, Tan's religious mentor, Taixu, echoed Tagore in telling Nehru that the present military crisis was attributable to Western modernity, which reduced humans to inorganic or material matters (Yinshun 1995: 251). In striking messianic rhetoric, Dai envisioned that China and India would act together and bring their moral rectitude to bear by 'subduing the demons that harassed the world and delivering salvation to humankind' (Dai 1959d: 1333-35). Finally, while pleading with the British to give Indians 'real political power', Chiang reminded Indians of the 'noble spirit of self-sacrifice' which they shared with the Chinese since antiquity and which 'should drive them to selfnegation for the salvation of mankind' (Chiang 1969: 665-68). ${ }^{4}$ Amidst the evocation of sacrifice, salvation and moral determination, Asia's fight against imperialism became a nebulous will to overcome the debased, materialistic West. Alarmingly, a variant of his drive to transcend 'materialism' was couched in terms of Japan's quest to replace mass consumer society with a new 'East Asia cultural sphere' (Harootunian 2000: 47-65). It was only that this endeavour took the form of a military showdown between Japan and the 'West'.

While Nehru did not shy away from the rhetoric of cultural commonality, his idea of Asian solidarity was clearly conditioned by his unease with capitalist social relations and analysis of the political and social conjuncture that produced the Second World War. He spoke warmly of Nationalist China and pledged support, appealing more to political affinities as fellow-nationalist movements than to ancient or civilizational ties. On 'Asia' as an alternative to a world dominated by the 'West', Nehru's assessment differed significantly from Tagore's. As late as August 1939, Tagore was still hoping Japan could retain her soul and not lose it to industrialized mass warfare. Nehru gently declined the poet's suggestion that he visit Japan after his trip to China, refusing to indulge in the illusion that Japan could be converted to 'peaceful and democratic ways' (Nehru 1977: 87-88). Indeed, purported racial affinities and the shared hatred for European domination did not endear Nehru to Japan, whose fascism he deemed as a vicious form of imperialism (Nehru 1976: 210). The left-leaning nationalist saw in China less a moral force that promised to save humankind from the nadir of Western

\footnotetext{
${ }^{4}$ The message was delivered as a radio broadcast by the English-speaking Soong May-ling.
} 
materialistic nihilism than a worthwhile partner in the global anti-fascist struggle of which India’s own fight against British imperialism was a part.

When Nehru wrote in the United States (US)-based journal, Fortune, in 1942 that Asia and Africa would play a critical role in determining the outcome of the Second World War, he meant nations that were subjected to the forces of imperialism and fascism (Nehru 2007b: 501). Nehru's notion of Asia-which he often mentioned alongside Africa, Spain and Soviet Russia-was thus not a geographical or cultural category pitched against Western civilization but colonized and semi-colonized peoples united in a global fight against imperialism. The imprint of his involvement in Comintern anti-colonialism, an experience which the GMD would rather forget, is obvious. Indeed, the Soviet experiment, like nationalist movements elsewhere, was, for Nehru, a laudable attempt to put an end to the hegemony of 'finance-imperialism' and the 'capitalist West' (Nehru 2007a: 479-85). Nehru's 'Asia' was a call for social changes which, for colonized peoples, was inseparable from the quest for national independence.

\section{FROM 'ASIA' TO THE 'THIRD WORLD'}

Nehru's internationalism was at odds with the GMD's faith in a morally pristine Asia and deep suspicion of communism. Yet more immediately noticeable rifts occurred within the Congress as Gandhi and the party's right wing, dismayed by Britain's intransigence, decided that India's independence could be secured under Japanese and Axis hegemony. With the launching of the Quit India Movement, Tan found himself pleading for Sino-Indian solidarity in a discourse that was much closer to Nehru's internationalism than to Tagore or Dai's Pan-Asianism. Disclaiming in September 1942 that as a 'simple Chinese Buddhist scholar', he had no interest in politics, Tan nonetheless proceeded to caution his 'Indian brethren' against Japanese pretense to anti-imperialism and support for India's independence. He even found it necessary to refute Gandhi, whose non-violence policy and spiritualism he strongly admired, and the Congress's argument that shifting from languishing under British imperialism to living within the Japanese sphere of influence amounted to nothing more than a 'change of Master'. Faced with the military prowess of a German-backed Japan, Tan adopted Nehru's position in urging India to support the Allies in order to save the world and India's aspiration for independence from 'be[ing] trampled under Hitler's iron heel' (Y. Tan 1999: 217-20). Tan's rare move away from his primary concern in 'cultural intercourse and co-operation' (ibid., 217) was a tacit acknowledgement that Pan-Asianism, with its inherent contradictions, ambiguities and mysticism, was no stable basis for a nationalist movement busy revising its strategies amidst the changing contours of global military and ideological conflicts.

China Report 46, 4 (2010): 353-370 
A much less documented, but perhaps more illuminating, incident revealing the limits of this idealist Pan-Asian diplomacy concerned the quiet unravelling of the alliance between Nationalist China and independent India in the few years leading up to the Cold War. In 1947, Tan played the unofficial diplomat again, as member of China's delegation to the Asian Relations Conference. The conference, held in the heady days shortly before the creation of the Indian state in 1947, was envisioned by Nehru as a forum to assert Asia's independence from European and American interests. Asian countries, he declared, must 'have their own policies in world affairs' and independent 'political, social and economic structure'. The prime minister-designate mentioned again Asia's affinity with Africa as fellow-colonized peoples fighting for national independence (Nehru 1948: 24-26). As an independent Asian nation-state, India was to have no part in helping the capitalist West in its suppression of communist and other national liberation movements in Southeast Asia, which Nehru saw not as malicious expansion of the Soviet empire but legitimate anti-colonial struggles (Nehru 2007c: 520). These strategies were to form the core of the anti-colonial non-aligned movement which Nehru and Zhou Enlai, premier of Communist China, gave rise to at the 1955 Bandung Conference (Prashad 2007: 31-50). ${ }^{5}$

The radical tone of Nehru alarmed the GMD, whose Pan-Asianist affinities with India were strained by its increasing involvement in the US-led global campaign against communism and its Chinese variant. Nanjing was also frustrated that Tibet, sovereignty over which Dai and Tan engaged in claiming, was extended an invitation to join the conference. In an article written for the GMD headquarters, Dai argued that while Nationalist China could not afford to simply turn down Nehru's invitation, it should send a delegation of academics and avoid commenting on anything of substance like international relations because 'China's position was different' from India as far as Europe and the US were concerned (Dai 1959b: 386-87). These 'scholars of pure mind', comprised of Tan and figures chosen from such GMD-affiliated organizations as the New Asia Society, the Sino-Indian Cultural Society or the Three People's Principles Youth Corps, were sent as a subtle snub of Nehru's plea for Third World solidarity. When Tan suggested, apparently nothing more than echoing the Sino-Indian Cultural Society, that an All Asia Cultural Association be set up to promote Asian culture and world peace, he was lampooning 'our fashionable socialist friends', to which Nehru probably belonged, and their vision of social change (Tan 1949: 6-9). Tan did suggest in another article, written not for the conference but for a magazine, that an 'Asia Union', with the multi-ethnic Singapore as its capital, be formed. But that Asia Union, as part of the Great World Union (datong), would be bound by nothing but amity, mutual help and self-sacrifice to offset the self-interest that energized imperialism, including that of Soviet Russia (ibid., 14-19). Tan was quick to assure that his musing on a post-national order was not intended to upset the status quo or 'existing powers

\footnotetext{
${ }^{5}$ For a much less generous assessment of the accomplishments of Bandung and the Third World project, see Ahmad (1992: 293-314).
}

China Report 46, 4 (2010): 353-370 
and interests' (ibid., 18). The apparently ambitious proposal for global and Asian unity, which under another set of circumstances played a pioneering role in mediating between the two nationalist movements of China and India, marked the parting of ways between the GMD's staunch anti-communism and the left nationalism of the newly created Indian state in the emerging Cold War order.

\section{CONCLUSION: THE LIMITS OF PAN-ASIANISM}

Both Cheena Bhavana and the Sino-Indian Cultural Society, re-founded as a body based solely in India, survived the financial fallout of China's communist revolution. As a member of an Indian state-funded university, Tan Yunshan welcomed Zhou Enlai to Cheena Bhavana in 1957 and received a one-off donation from the communist premier (Tan 1957: 50). This, however, could not hide the fact that the school no longer had the significance in Sino-Indian relations that it once possessed. This shift was partly a result of the presence of formal state-to-state diplomacy and the unravelling of the British empire, which rendered the mediating role of 'apolitical' figures like Tan, with his connections in and freedom of movement between various British colonies in Asia, less important. It also marked the fact that the Pan-Asianist idealism that Tagore and Tan represented was no longer compatible with the internationalist agendas of either independent India or Maoist China.

That the romantic longing for the unity of Asia as a religious and aesthetic category was no blueprint for political action was, in a way, to be expected. Tan emphasized numerous times that he cared about nothing but culture, even when he was obviously making political statements. This seemingly contradictory claim suggested not that Tan was disingenuous but that his involvement in state affairs and vision of Asia was not tainted by consideration of interest, 'self-preservation' or, as Taixu and Dai often put it, materialism. In fact, the privileging of culture in the Visva Bharati experiment was informed by a renunciation of social purpose and productive labour, a result of Tagore's disillusionment with Swadeshi mobilization (Sartori 2008: 188-89). Tagore and Tan's plea for Asia to replace the calculated violence of modernity took on the universalist quality of Kantian aesthetics, in that it effectively proposed a complete disregard of interest and the gravity of political power structures and social relations (Eagleton 1990: 97).

The pitfalls of this disinterested aesthetics were succinctly revealed by Karatani Kôjin in his analysis of the ambiguous relationship between many Japanese intellectuals and state expansionism during the Pacific War. Reading wartime figures like Yasuda Yojûrô and Nishida Kitarô, whose intellectual genealogy could be traced to the great Pan-Asianist Okakura Tenshin, Karatani observes how romantic disinterestedness negated the task of overwhelming social contradictions as any aporia was deemed to have been sublated a priori in one's consciousness. This procedure allowed Yasuda,

China Report 46, 4 (2010): 353-370 
Nishida and others to deny the need for active political programmes and simply attribute the surmounting of contradictions to present developments. Thus, Japan's Greater Asia Co-prosperity Sphere was idealized as being a superior alternative to both the capitalist nation-state system and Soviet internationalism (Karatani 2005: 106-14). Tan and Tagore, to be sure, had no illusion about Japan's continental ambitions. Yet, their call for Asia's spiritual unity and disdain for any consideration of interest resulted in a politics that dovetailed nicely with the GMD's anti-revolutionary revolution of consciousness as the party actively oppressed any 'materialist' challenge to the social structure. Tagore's paean to Chiang Kai-shek in his debates with Yone Noguchi or Tan's pledge that his proposal of Asia Union would accommodate Cold War geopolitical configurations were certainly no GMD propaganda, but they did not contribute to effective critiques of twentieth century imperialism either.

The spread of civilization discourse since the mid-nineteenth century as a transnational means of imagining and constructing autonomous collective subjects free from both social determinants such as economics and Western domination was contingent on the temporality of capitalist modernity (Sartori 2008: 21-22, 43-47). It is thus hardly surprising that in the last decade or so, the rise of the Indian and Chinese nation-states as enthusiastic participants in the capitalist world order has injected contemporary relevance to the remarkable careers of Tagore and Tan in the first half of the twentieth century. Tagore's literary corpus circulates in the Chinese market as a treasure trove of Valentine's Day messages and 'soothing balm' for pressurized white-collar workers. Even his Pan-Asianism, long an object of ridicule for the Chinese communists, seems to be re-emerging as an attractive possibility set against the ongoing Euroamericacentred financial crisis (Basu 2010), not unlike how Asia was touted as an alternative civilization to war-ridden Europe in the wake of the Great War. In India, China and elsewhere, Tan Yunshan's equally peripatetic son Chung, a historian of China, inherits his father's mission by calling for a geo-civilizational paradigm to envision a future relationship between the two societies to replace hard-nosed geopolitical calculations (Tan 2009). While Tan Chung's model of 'Chindian interactivism' draws directly from the Asian spiritualism Cheena Bhavana embodied, it has reconciled to the fact that the two societies are now full-fledged nation-states. Having witnessed the dramatic deterioration of Sino-Indian relations in the 1960s, Tan Chung is much more forthcoming in critiquing the virulent effects of right-wing nationalisms and rivalries backed by the two Cold War superpowers (Tan 2006: 25-26). More notably, in the same preface to a Chinese translation of a book written by the Congress politician Jairam Ramesh, a main figure in Manmohan Singh's economic liberalization programme, Tan Chung gently rebuked the argument that contemporary India-China interactions are ultimately conditioned by realist considerations. Citing Nehru's internationalist solidarity with China during the Second Sino-Japanese War, he observes that while economic interests are important, one should not be too quick to discount ethical and political principles (ibid., 30-31). Lying not far beneath evocations of Xuanzang and Tagore are pointed complaints about the Cold War experience and

China Report 46, 4 (2010): 353-370 
ongoing economic globalization. Whether revived pleas for Sino-Indian fusion adopt a more critical edge and point towards genuine rapprochement between the two societies or merely serve as the backdrop to the integration of two expanding economies would be of great interest far beyond the academic community.

\section{REFERENCES}

Ahmad, Aijaz, In Theory: Classes, Nations, Literatures (London: Verso, 1992).

Basu, Chitralekha, 'Hope of the East', China Daily, 14 May 2010, http://www.chinadaily.com.cn/life/201005/14/content_9849785.htm (accessed on 11 June 2010).

Bharucha, Rustom, Another Asia: Rabindranath Tagore and Okakura Tenshin (New Delhi: Oxford University Press, 2006).

Cheung, L.K., 'Hegemony and the Formation of Organic Intellectual: Qu Qiubai and the Revolutionary Politics of Early 20th Century', PhD Thesis, The Chinese University of Hong Kong, 2007.

Chiang, Kai-shek, 'One Half of the World's People', comp. by Chinese Ministry of Information, Collected Wartime Messages of Generalissimo Chiang Kai-shek, 1937-1945 (New York: The John Day Co., 1969), pp. 665-68.

Dai, Jitao, Dai Jitao zuijin yanlun (The latest remarks of Dai Jitao), 2nd Edition (n.p.: Shangwu yinshuguan, 1928).

—. Sun Wen zhuyi zhi zhexue jichu (The philosophical foundation of Sun Yat-senism) (Taipei: Zhongyang gaizao weiyuanhui wenwu gongyingchu, 1951 [1925]).

—_ 'Zhong Ri E san minzu zhi guanxi' (The relationship between China, Japan and Russia), in Chen Tianxi (Ed.), Dai Jitao xiansheng wencun (Taipei: Zhongguo Guomindang zhongyang weiyuanhui, 1959a), p. 372.

—_ 'Dui Yindu Nihelu faqi zhaoqi fan-Ya huiyi zhi ganxiang' (Thoughts on Nehru’s Convening of the Asia Relations Conference), in Chen Tianxi (ed.), Dai Jitao xiansheng wencun (Taipei: Zhongguo Guomindang zhongyang weiyuanhui, 1959b), pp. 386-87.

_ _ 'Gaobie Yindu renshi shu' (Farewell message to Indian notables), in Chen Tianxi (ed.), Dai Jitao xiansheng wencun (Taipei: Zhongguo Guomindang zhongyang weiyuanhui, 1959c), pp. 1291-92.

, 'Zhong Yin liangguo guomin de jiushi jingshen' (China and India's spirit of universal salvation), in Chen Tianxi (ed.), Dai Jitao xiansheng wencun (Taipei: Zhongguo Guomindang zhongyang weiyuanhui, 1959d), pp. 1333-35.

—_ 'Zhi Taiguo'er xiansheng zhesi shu' (Letter to Rabindranath Tagore's son), in Chen Tianxi (ed.), Dai Jitao xiansheng wencun (Taipei: Zhongguo Guomindang zhongyang weiyuanhui, 1959e), pp. $1645-46$.

—, Lun Riben (On Japan) (Beijing: Jiuzhou chubanshe, 2005 [1928]).

Duara, Prasenjit, Sovereignty and Authenticity: Manchukuo and the East Asian Modern (Lanham, MD: Rowman and Littlefield, 2003).

Eagleton, Terry, The Ideology of the Aesthetic (Oxford: Basil Blackwell, 1990).

Guha, Ranajit, 'Discipline and Mobilize', in Partha Chatterjee and Gyanendra Pandey (eds), Subaltern Studies VII (Delhi: Oxford University Press, 1992), pp. 69-120.

Harootunian, Harry, Overcome by Modernity: History, Culture, and Community in Interwar Japan (Princeton: Princeton University Press, 2000).

Karatani, Kôjin (Trans and edited by Richard Calichman), 'Overcoming Modernity', Contemporary Japanese Thought (New York: Columbia University Press, 2005), pp. 101-18.

Kubo, J., 'Zasshi Shin Ajia ronsetsu kiji mokuroku' (Catalogue of Commentaries and Articles in the Journal New Asia), Kôbe daigaku shigaku nenpô, 2002, No. 17, pp. 80-124.

China Report 46, 4 (2010): 353-370 
Lin, Hsiao-ting, Tibet and Nationalist China's Frontier: Intrigues and Ethnopolitics (Vancouver: UBC Press, 2006).

Nehru, Jawaharlal, Inaugural Address at the Asian Relations Conference, 23 March 1947, reprinted in Asian Relations: Report of the Proceedings and Documentation of the First Asian Relations Conference (New Delhi: Asian Relations Organization, 1948), pp. 24-26.

-, 'Why India Supports China', in S. Gopal (ed.), Selected Works of Jawaharlal Nehru, Vol. 9 (New Delhi: Orient Longman, 1976), pp. 209-10.

_ ' 'Diary of a Journey', in Selected Works of Jawaharlal Nehru, Vol. 10 (New Delhi: Orient Longman, 1977), pp. 84-100.

Nehru, Jawaharlal , 'India in the World', in Uma Iyengar (ed.), The Oxford India Nehru (New Delhi: Oxford University Press, 2007a), pp. 479-85.

— ' 'India's Day of Reckoning', in Uma Iyengar (ed.), The Oxford India Nehru (New Delhi: Oxford University Press, 2007b), pp. 498-507.

— 'Basic Principles', in Uma Iyengar (ed.), The Oxford India Nehru (New Delhi: Oxford University Press, 2007c), pp. 519-24.

Neocleous, Mark, Fascism (Minneapolis: University of Minnesota Press, 1997).

Prashad, Vijay, The Darker Nations: A People's History of the Third World (New York: The New Press, 2007).

Qu, Qiubai, 'Taige'er de guojia guan yu Dongfang' (Tagore's views on the nation-state and the East), in Qu Qiubai wenji bianji zu (ed.) (Works of Qu Qiubai editorial collective), Qu Qiubai wenji: zhengzhi lilun bian, Vol. 2 (Beijing: Renmin chubanshe, 1988), pp. 511-19.

Sartori, Andrew, Bengal in Global Concept History: Culturalism in the Age of Capital (Chicago: The University of Chicago Press, 2008).

Tagore, Rabindranath, Letter to Tan Yunshan, 14 February 1939, in Tan Yunshan (ed.), Twenty Years of The Visva-Bharati Cheena-Bhavana, $1937-1957$ (Santiniketan: The Sino-Indian Cultural Society of India, 1957a), p. 40.

- 'China and India', in Tan Yunshan (ed.), Twenty Years of The Visva-Bharati Cheena-Bhavana, 1937-1957 (Santiniketan: The Sino-Indian Cultural Society of India, 1957b), pp. 41-45.

— Letter to Yone Noguchi, 1 September 1938, in Tan Chung (ed.), In the Footsteps of Xuanzang: Tan Yun-shan and India (New Delhi: Gyan Publishing House and Indira Gandhi National Centre for the Arts, 1999), pp. 209-11.

Tan, Chung, 'Tan Yun-shan: A Historical Role', in Tan Chung (ed.), In the Footsteps of Xuanzang: Tan Yun-shan and India (New Delhi: Gyan Publishing House and Indira Gandhi National Centre for the Arts, 1999), pp. 13-35.

— 'Zhongwen ban qianyan' (Foreword to the Chinese edition), in Jairam Ramesh, Lijie Chindia: Guanyu Zhongguo yu Yindu de sikao (Making sense of Chindia: Reflections on China and India) (Yinchuan: Ningxia renmin chubanshe, 2006), pp. 1-33.

—, 'The Chindian Key to Open the Geo-civilizational Paradigm', Speech delivered at the Second China-South Asia International Cultural Forum, New Delhi, 5 December 2009.

Tan, Lee, 'Life Sketch of Tan Yun-shan', in Tan Chung (ed.), In the Footsteps of Xuanzang: Tan Yun-shan and India (New Delhi: Gyan Publishing House and Indira Gandhi National Centre for the Arts, 1999), pp. 1-12.

Tan, Y., Inter-Asian Cultural Co-operation and Union of Asia, Sino-Indian Pamphlet, No. 13 (Santiniketan: The Sino-Indian Cultural Society in India, 1949).

Tan, Yunshan (ed.), 'My Devotion to Gurudev', in R. Narasimhan (ed.), Gurudev Tagore (Bombay: Hind Kitabs, 1946), pp. 1-6.

—, 'His Excellency Dr. Tai Chi-t'ao: A Biographical Introduction', in Dai Jitao, Goodwill Messages to India, Sino-Indian Pamphlet, No. 11 (Santiniketan: The Sino-Indian Cultural Society in India, 1948), pp. i-vi.

China Report 46, 4 (2010): 353-370 
Tan, Yunshan (ed.), Twenty Years of The Visva-Bharati Cheena-Bhavana, 1937-1957 (Santiniketan: The Sino-Indian Cultural Society of India, 1957).

, 'An Appeal to Conscience', in Tan Chung (ed.), In the Footstep of Xuanzang: Tan Yun-shan and India (New Delhi: Gyan Publishing House and Indira Gandhi National Centre for the Arts, 1999), pp. 217-20.

Voigt, Johannes H., 'Co-operation or Confrontation?: War and Congress Politics, 1939-42', in D.A. Low (ed.), Congress and the Raj: Facets of the Indian Struggle, 1917-47, 2nd Edition (New Delhi: Oxford University Press, 2004), pp. 349-74.

Yinshun, Taixu fashi nianpu (Chronological biography of the Venerable Master Taixu) (Beijing: Zongjiao chubanshe, 1995).

Zhu, L. 'Between Truth and Imagination: Special Envoys on Mission to Tibet during the Period of Republican China, 1912-1949', PhD Thesis, The Chinese University of Hong Kong, 2006.

Author’s address: 14A Cumine Court, 52 King's Road, North Point, Hong Kong. E-mail: bkt2103@columbia. edu 